http://www.jfas.info

\title{
ETHNOCULTURAL FEATURES OF A LINGUISTIC PERSONA: THE SPECIFICS OF THE REPRESENTATION OF UNIVERSAL EMOTIONAL CONCEPTS
}

\author{
S. K. Bashieva, M.Ch. Shogenova*, Z. R. Dokhova, I. R. Tabaksoeva \\ Kabardino-Balkarian State University named after H.M. Berbekov, 173-Chernyshevskogo \\ Str., Nalchik, Kabardino-Balkar Republic, 360004
}

Published online: 08 August 2017

\begin{abstract}
The work is performed within a framework of modern linguistic and cognitive research as well as linguistic and cultural research aimed at studying the significance and value of the ratio of "language-culture-persona" triad components. Their interdependence enables to define ethnocultural features of a linguistic persona and an "ethnocultural" index in its structure.

The main goal of this paper is to study the specifics of an ethnocultural worldview as one of the principles of understanding the world around through the explication of ethnically marked conceptual units represented in the emotional and sensual linguistic model.

The research emphasizes that typical cognitive processes enable to comprehend the phenomena of the world around and determine the similarity of representation and adequate interpretation of certain emotions and feelings of people within a framework of one ethnic community. It proves the assertion that the structure of a linguistic persona under study has an emotional and sensual level as a set of culturally determined universal and nationally marked concepts expressed and represented by linguistic means that enable to conceptualize the semantics of emotions as markers to define the ethnocultural specifics of a linguistic persona. The paper pays special attention to the ethnocultural content of emotional and lexical units, which indicate the ethnic identity of a linguistic persona and reflect typical, historically developed signs of the ethnic image of the world.
\end{abstract}

Author Correspondence, e-mail: bfo-pdo@mail.ru

doi: http://dx.doi.org/10.4314/jfas.v9i2s.866 
Illustrative and research material of the paper represented by paroemiological and phraseological units, formulas of speaking etiquette, and ethnic concepts of primarily a Kabardian and Balkar culture of the dominant peoples of the Kabardian and Balkar Republic and partially a Russian culture, allows us to prove that the conceptual meaning of universal emotionally rich lexemes enables to identify and to assess the specifics sensual worldview of a particular ethnic group; that every ethnic culture develops its own system of notions and meanings marked by an emotional index, which defines both the psychological portrait of a person and the specific features of his ethnic conceptual worldview; that the emotional world picture of a linguistic persona is based on a binary way to perceive the world and an evaluative and axiological (value) principle of the subjectivation of an objective world; that emotional state of a person and specific expression of a sensual worldview become indicative of his ethnocultural identity.

Keywords: linguistic persona; ethnocultural linguistic persona; emotional and sensual worldview; cognitive activity; cognition; cognitive and evaluative markers.

\section{INTRODUCTION}

The research into the specifics of a linguistic persona development is one of the most significant issues in a modern anthropocentric paradigm, which focuses on a person and his activities and is represented as a many-fold and multi-aspect category and a social and cultural phenomenon. As we know, this understanding of a linguistic persona appeared in science as early as in the 18-19th centuries and was reflected in the works of W. von Humboldt [1984; 1985], and J.G. Herder [1977]. It was further developed in the works of L. Weisgerber [2004]. He was the first to pay attention to the individual character of the knowledge of a language. In modern Russian linguistics, a thorough research of a linguistic persona relates to the 1980s. It is associated with the names of G.I. Bogin who offered a linguistic and didactic theory of studying a linguistic persona as a person seen from the viewpoint of his readiness to perform speech actions [Bogin 1984: 25], and Yu.N. Karaulov who defined a linguistic persona as a “...persona expressed in a language (texts) and through a language, as a persona reconstructed in its basic traits on the basis of linguistic means" [Karaulov 2007: 38]. Now, the term linguistic persona occupies a strong position in modern research, which highlights that this phenomenon as a significant area of multi-aspect research is many-fold. This research deals, among other things, with the creation and development of a linguistic persona in the context of culture, which is a quite a relevant issue.Culture and language are the forms of consciousness; their interdependence is determined by a common 
subject - a persona as a carrier of a language and culture. B.N. Teliya assumes that "it is persona that is in the center of everything - language and culture" (from the discussion of March 22, 2011) [cit. ex Zykova 2013: 34], and “...this is quite expected, since the subject of a language is always the subject of a culture" [Teliya 2005: 9].

A culture born in ethnic (national) depths seems to be the most powerful and effective means of self-expression and manifestation of a persona in the world around and the establishment of the status and identity of an ethnic group in the various space of human being. Determined association between a language and a culture specifies a "translational" way of its development related to a "genetic program" [Tarasov 1993: 10], which is executed as a historically conditioned cultural project in a linguistic system that represents the specifics of the worldview of the entire nation and a particular persona.As a carrier of cognitive and communicative abilities, a linguistic persona fixes worldview, philosophic and moral potential of its ethnic group and develops the acquired knowledge and experience in the ethnic concepts, which form a linguistic picture of the world. A linguistic persona in the context of a culture is a mediated subject capable of objectivizing and verbalizing the results of perception and comprehension of reality.Indeed, the cognitive level in the structure of a linguistic persona enables to cumulate knowledge of the world around and its axiological reference points, i.e. cognitive potentials and abilities of a linguistic persona. A.P. Sedykh assumes that "...it is cognitive and communicative potential...that is a priority for revealing dominant traits of a national linguistic persona" [Sedykh 2005: 5].

In this aspect, we find it important to treat the specific representation of emotional concepts by a linguistic persona as a set of culturally determined universal and nationally marked specific feelings, which define the ethnic character as a principle element of a traditional culture. I.V. Zykova assumes that an emotional and sensual experience develops a fund of primary and basic representations of the world around [Zykova 2011:19]. People have different concentration of emotions, emotional density, resilience, and mental strength. However, they may behave in the same way and feel or express relatively similar feelings in standard emotional situations. Therefore, the emotional experience of a linguistic persona varies a lot and emotions in its structure may be revealed more or less actively (vividly, convincingly) depending on ethnic identity. Thus, ethnocultural mentality of one nation predetermines the intended reduction of an emotional index of the manifestation of feelings, while, in the culture of another ethnic group, there is a tendency to open manifestation of feelings and emotions. In this respect, V.I. Shakhovsky writes that "It turns out that linguistic personalities certainly cannot reflect, chart and interpret the world (unfortunately, different 
ethnic groups have different worlds, despite the popular opinion in science) in different ethnic groups by using different linguistic codes based on different memories of the historical period of these ethnic groups" [Shakhovsky 1996: Pp. 29-30].

The correlation between the emotional world of a linguistic persona and its national and cultural identity is activated in V.I. Shakhovsky's theory. He emphasized that "an emotion is a core of a linguistic persona" [Shakhovsky 2008: 48] and that “....any linguistic persona knows what an emotion is" [Shakhovsky 2008, p. 46], therefore, in every person, there develops an emotional linguistic persona. Besides, it is covered in the premises of N.A. Krasavsky who assumes that a "speaking person is certainly a mental person [Krasavsky 2001: 24]; and observations of A.T. Khrolenko who noticed that “...a dictionary of emotive lexis that verbalizes an emotional experience is different in different languages. This difference is conditioned by the national character and culture" [Khrolenko 2007].

Therefore, the relevance of the issue is associated with the cognitive activity of a person, the results of which are largely based on the processes of world conceptualization and verbalization of knowledge in the ethnic consciousness of a person. However, we should highlight that a modern linguistic persona develops in a variety of cultures, in the interdependence and interinfluence of nations, and in an enlarging dialogue of civilizations in the global and integrational world, in which we should protect ethnic and cultural originality. Besides, these tendencies enhance the value of this research aimed at creating a methodological (conceptual) basis to define the specifics of an ethnocultural fragment in the structure of a linguistic persona under study as the results of its cognitive activities in the context of its own perception and comprehension of the world and the real representation of the acquired knowledge.

Obviously, there are complex and contradictive processes of the establishment of a national identity in the context of coexistence in a single spatial and temporal system of various types of cultures and traditions in the cultural and communicative space of modern Russia. In a climate of an unusual ethnic variety of the Kabardian and Balkar Republic, one of the Russian and Caucasian subjects, a historical experience of the development of a unique cultural and communicative space, where more than 70 ethnic groups coexist, have been accumulated for a century. The representatives of the Russian ethnic group and the Kabardian and Balkar nations (dominating nations in the republic), constitute the majority of the population. They form a background for the development of a linguistic persona with its ethnocultural peculiarities. Therefore, the issue of revealing ethnocultural features of a linguistic persona through the specifics of the representation of universal concepts including emotional concepts 
becomes significant and relevant from the perspective of the theory and practice of the research into a linguistic persona.

\section{MATERIALS AND METHODS}

The material of the research is mythologized linguistic units, paroemiological and phraseological units, formulas of speaking etiquette, and ethnocultural concepts, which reflect the results of the cognitive comprehension of the world around by a linguistic persona and represent, among other things, an emotional worldview.

The methods of research are an analytical method; a method of generalization and systematization; a method of interpretation, a method of linguistic observation over the functioning of linguistic units in various discourses.

\section{RESULTS}

1. The term "linguistic persona" occupies a strong position in modern research. It represents a significant area of multi-aspect studies, which involve quite a relevant issue of the development of a linguistic persona in the context of an ethnic culture.

2. An emotional and sensual worldview is understood as one of the universal ways for a linguistic persona to cognize reality, as a determinant of its actions and deeds, as an indicator of subjective worldview and evaluation, as an index of identity (solidarity) with a certain group of people with similar emotional features etc.

3. Emotional concepts are a means of ethnocultural world modelling. These are cognitive and evaluative markers in the ethnic consciousness of an ethnic group and a linguistic persona; they are embodied and preserved in the linguistic consciousness of an ethnic group as both universal (panhuman) and ethnic representations and values of the emotional perception of reality.

4. Each ethnic culture develops and elaborates its own system of notions and meanings marked by an emotional index. This system seems to be a complex hierarchy of verbalized meanings and correlations of emotionally rich lexical units, whose semantics, despite their universal nature, is primarily subdued to a single ethnic coordinate, which predetermines the specific development of a cognitive level of a particular linguistic persona.

5. Emotional characteristics of a person as an indicator of his ethnic and cultural identity are often an indicator of a linguistic persona. It is emotional and sensual perception islaid down in a language, and, therefore, enables to reveal many typical, historically developed signs of an ethnic image of the world. In particular, these features are found through the ethnocultural 
code as a way to symbolize a real world and to represent emotional concepts verbalized in idioms, paroemias, phraseological units, and texts written in a language and created by conventional and creative metaphors.

6. An emotional worldview of a linguistic persona is often based on semantic binary oppositions, which represent the specifics of an ethnic culture. They are one of the most relevant principles of learning and describing a thesaurus of a linguistic persona, while an antonymic picture created at the linguistic and cognitive level of a linguistic persona contributes to the explicit reflection of the representations of the world.

\section{DISCUSSION}

The emotional description of a persona acquires its line and arrangement in the linguistic explication, which is represented in typical real situations understood as fragments of the world picture that represent the emotional cognition of what is going on. Basic (universal) emotions are interpreted in every culture. They mark a cultural and linguistic code and define the ethnocultural specifics of a linguistic persona. They vary in different ethnic cultures and have different emotional index of activity. They are filled with evaluative and value representation of a particular ethnic group and are expressed by linguistic means, which enable to conceptualize the semantics of emotions.

We refer certain emotions (feelings) to basic emotions primarily because they are typical and, most importantly, due to their perceptive determination. Thus, the feelings of joy, surprise, fear, and sadness are inherent of a person. They are not just universal responses to what is going on, but also "the most relevant cultural phenomenon of an ethnic group" [Krasavsky 2001: 25]. A nominate of a universal emotion is a word (substantive), which denotes a relevant typical emotion (for example, the situation of the manifestation of fear, joy, anger, and sadness). Fundamental feelings of a person, which are nominated and embodied in relevant concepts, predetermine the conditions of the creation and development of a system of other emotions, albeit secondary, that also enable to consider their ethnocultural signs in the structure of a linguistic persona. Basic feelings have a lot of typical signs that reflect the emotional state of a person in a standard life situation. Typicality and similarity in the perception and manifestation of some fundamental emotions in various ethnocultural linguistic pictures, and, therefore, in the conceptualization of feelings experienced by a persona are revealed, for example, in the context of an ethnocultural code. Thus, a sudden euphoria, an unexpected feeling in various linguistic pictures of the world (including Russian, 
Kabardian and Balkar) is rendered by the same somatic code and revealed in the expressions that are equal in the subjective perception and metaphorical representation: udarit $v$ golovu (Rus.) and shchkh'em deueyashch (Kab.), bashyna (zhengil, terk) chabarg"a (Balk.) - to get into head; the feeling of an acute, emotional surprise or fear is rendered in the phrases glaza na lob lezut (Rus.) - his eyes nearly fell out of his head, and ner k"ikhuashch (Kab.) - the eyes have fallen out (literally); kezleri zhanarg" $a$ (Balk.) - the eyes are burning (literally); kezleri mangylayyna chyg"arg"a (Balk.) - the eyes started from their sockets; the emphasized manifestation of a respectful, kind and sincere feeling to someone is expressed by the words nosit' na rukakh (Rus.) - to carry in one's arms, Iegum isu k"ekh'ekIyn(Kab.) - to carry on a palm (literally), $k^{\prime \prime}$ ol ayazda zhyuryutyurge (Balk.). Typical lexical units are also found in the aspect of other cultural codes. Thus, the sense of offence and discontent is rendered in the phraseological units nadulsya kak indyuk (Rus.) - guegushykh"uu zyk"ig"epshchashch (Kab.) - he has swollen like a turkey-cock (literally), gogush kibik keberge (Balk.) - he has swollen like a turkey-cock (literally); (a zoomorphic code); the expression of anger, reproaches, and severe criticism of someone (something) is compared to a thunder - gromy $i$ molnii letyat, razrazilis' (colloquial, expressive) - thunders and lightning are flying [literally], uafe g"uag"ueu k"ytkhykh'ashch (Kab.) - to come like a thunder (literally),raged ( a biomorphic code); a feeling of a person who abuses - palka po tebe plachet (Rus.) you will have a stick (literally)-bashyr k"ypl"ysnushch (Kab.) - you will have a stick (literally) - tayak" zheterge (tierge) (Balk.) - you have a stick in the meaning to abuse (a subject code).

In the context of our problem, we need to show the emotional essence of a linguistic persona in the ethnocultural format, since we assume that the structure of a linguistic persona develops an ethnically and culturally determined emotional model of responding to typical life phenomena rendered in basic emotions and feelings. A.P. Sedykh assumes that “...linguistic forms, which have ethnocultural traces in their meaning, affect the thinking paradigm of native speakers and encourage them to use specific and nationally determined imagery elements [Sedykh 2005 69]. Thus, the cultural value of the word "soul" is equal to the value of a person himself. This is his mentality, specifics of thinking and an indicator of his priorities. S.G. Vorkachev assumes that a soul is the only way to express a bodiless and challenging abstraction in a sensual image [Vorkachev 2003: 57]. When we define an emotional component of a linguistic persona, a soul is understood as an internal mental world of a persona and its consciousness, the concentration of person's dominant feelings. In this paper, we treat a soul as an ethnic sign and a whole system, which involves both primary and higher levels of manifestation of people's emotional energy, its will and desires, the character 
of an ethnic group, as an evaluative paradigm in the structure of a linguistic persona, as a primary perception of the world, as a prerequisite for the development of an emotional concept understood as "some pattern of behavior based on an emotion or emotions and reflected in the consciousness, which can be described in the context of social cooperation between people." [Chesnokov 2008: 37].

The word soul is a cultural dominant in many linguistic pictures of the world. It expresses ethnic priorities in the spiritual and moral development of both a nation and a particular individual and represents ethnocultural specifics of the embodiment of persona's sensual world.At the verbal and semantic level of a linguistic persona, there is some fixation of key concepts including emotional and sensual words, which reflect the mental model of the world perceived. The emotional and conceptual content of the notion soul is primarily determined by the cultural and national (ethnic) specifics of its responding to the processes in the world around. It is true that a soul is a concentration, a source, a generator of various forms of manifestation of a spiritual experience as a core of the spiritual base of culture. "It takes or somehow "generalizes" the cognitive experience of many generations" [Zykova 2011: 43]. Therefore, it is true that a soul is a generalized and culturally and ethnically determined national view, which embodies the specifics of worldview and evaluation of ethnically united people, a concentration of people's mentality.

Thus, the concept duscha (soul)is especially relevant in the understanding of the Russian mentality and refers to basic, universal concepts of the Russian culture. A. Vezhbitskaya assumes that "...in the Russian language, dusha(soul), or sudba (destiny) are like a free end found in a tangled ball of wool: if we pull it, we would possibly unravel the entire tangle of attitudes, values and expectations embodied both in words and popular combinations, set expressions, grammatical constructions, proverbs etc." [Vezhbitskaya 2010: 37]. A soul occupies a special place in the emotional world of a particular linguistic persona, since its essence is often equaled to a person himself. Thus, it is no coincidence that set expressions russkiy dukh [a Russian spirit], shirota russkoi dushi [a big Russian soul] are perceived as ethnic markers of the Russian ethnic culture, ethnic identity, and Russian nation. Universal human feelings emerge as responses to the manifestations of the external world and fixe the results of world cognition in a soul through a language "at the level of conceptual metaphors that reflect person's various representations of his soul." [Kondratyeva 2014: 69]. Thus, the feeling of joy in the soul is verbalized in the same way at the semantic level of a relevant linguistic persona and is associated with something "live" that is likely to move throughout the coordinate to depart-to return. Therefore, the departure of a soulexpresses negative 
emotions, while the return of a soul renders positive emotions. Thus, the feeling of anxiety is rendered by the expressions dusha ne na meste (Rus.), dusha ushla v pyatki (Rus.) - a soul is not at its place, a soul went to heelsout - literally, pser khekIashch, ukIashch (Kab.) - a soul departed, a soul went out - literally; zhany keterge (Balk.) - a soul went out (because of fear) (literally); to render the feeling of joy, change of mood, feeling of some revival, a burst of positive emotions, the set expressions vospryanut' dukhom (Rus.) - to acquire a good mood, energy, to become revitalized, pser $k^{\prime \prime} y k h y k h$ 'ezhyn (Kab.) - to become reanimated, to become joyous again - a soul has returned - literally; zhan kirirge (Balk.) - a soul has entered (literally) are used. An ethnic linguistic persona expresses other basic emotions in a similar way by using the lexical unit dusha: a sense of suffering - dusha bolit, dusha nadryvaetsya, dusha razryvaetsya na chasti - a soul aches, a soul suffers, a soul is torn into pieces literally; sense of pity - dusha perevertyvaetsya (perevernulas') - a soul is turning, a soul turned down - literally; sense of trouble - dushoy bolet' - to have one's soul aching literally; sense of sadness, anguish, trouble, anxiety - skrebet na dushe (koshki skrebut na dushe) - scratching in the soul (cats are scratching in the soul) - literally etc. In the speech of an Adyghelinguistic persona, a soul (pse - Kab.) is also verbalized by emotional words and expressions and is associated with a living sensual organism that experiences all fundamental (basic) emotions. Thus, pser "eyrt (Kab.)means trouble, anxiety; pser k"ykhek"ezhashchmeans to give life, joy, rest, feeling of revival back to someone; and pser Iukhyn (Kab.) to frighten, to make heart quake [literally: to remove a soul, to take a soul from someone]; psem zig"epsekhuzhashch (Kab.) means a soul calmed down [literally a soul had a rest]; psem khemykhyn, psem khel"ym khemykhyn (Kab.) -a sense of sincerity and love [literally do not remove from a soul; do not remove from everything that a soul has] etc. In the Balkar picture of the world, a linguistic persona also uses the world soul (zhan - Balk.) in the context of rendering person's emotional feelings. Thus, at the verbal level, we find such combinations and words as zhany $k^{\prime \prime y y n a l y r g "} a$ (Balk.) - a soul is suffering (literally) in the meaning to trouble, to feel anxious (someone); a feeling of distraction, fear - zhany tamag"yna tyg"ylyrg" $a$ (tigelerge) (Balk.) - a soul reached the throat (literally) - in the meaning to be in a severe state because of fear; a feeling of anxiety and trouble - zhanyn k"oluna alyp (aylanyrg"a) (Balk.) (to walk) with one's soul in hands in the meaning to suffer, to fear; a feeling of love - zhany kibik keryurge (Balk) - to see like one's soul (literally) to love very much etc.

Meanwhile, the word soul as a basic notion of different cultures has some specifics of collocability and semantics and sometimes, it is difficult for a person of another culture to 
understand its linguistic explication. A.P. Sedykh assumes that "...emotivism affects the system of representations of the world, social organization and semantic manifestation of certain elements in the structure of meaning of linguistic units that correlate with person's emotional condition" [Sedykh 2012: 110]. Thus, this assertion is proved by the use of such expressions as ui adem $i$ pseshch!Ui adem $i$ bynshshch ar!(Kab.)-this is the soul of your father! these are children of your father (literally); ui pseshch ar, ui adem i pseshch ar- this is your soul, this is the soul of your father - Not a bit of it!; it actualizes another significant concept - in this case, a high status and significance of the role of father in the representation of an Adyghelinguistic persona; pse zepyl"kh'epIeshch (Kab.) -a feeling of extreme danger [literally: a place where a soul connects to something, the concepts life and death enhance]; a Balkar linguistic persona can render a feeling of extreme fear by the phrase zhanyn uuuchkha zhyyarg"a (Balk.) [literally to gather a soul in a fist], which expresses person's appeal to be firm and to cope with fear; zhany zher bla teng bolurg" $a$ - a soul has become equal to earth (literally) in the meaning to be extremely sad, upset, which does not allow to raise above the ground - a conceptualization of the top-bottom opposition, and compares the state of extreme joy with the feeling of height teppesi kekge zheterge (Balk.) [literally top of the head reaches the sky]; a Russian linguistic persona can render the state of a soul by the concept of kamen (stone)as a symbol of hardiness and solidity - a sense of heaviness and depression is associated with kamen na dushe (Rus.) [literally, the stone in the soul], while a feeling of mental relief and freedom from a depressing and unpleasant state is rendered by the expression kamen s dushi svalilsya (Rus.) [literally a stone fell down the soul] etc. The analysis of similar specific expressions represented as a minimum cultural text, which renders the worldview of an ethnic group, enables to reveal different degrees of manifestation of emotionality to identical feelings and experiences, which determines the development of a specific emotional linguistic persona with various degree of emotional indexation. Indeed, "different cultures have a different attitude to various emotions and give social connotations to the experiences and manifestations of particular emotions, which influences education and socialization [Sedykh 2012:110].

Emotional state of a person is determined by cognition and reflects his experience fixed in the linguistic memory of a persona as associative and imagery connotations. The emotional state of a person, metaphorical perception and expression of some feelings is influenced by many factors including climatic life conditions of an ethnic group, a natural image of its life, a historical destiny, a cultural level of social development, a degree of ethnic diversity etc. Therefore, we find it possible to focus on a cultural ideal of the emotional behavior of an 
ethnic linguistic persona in expressing basic emotions and to consider the specifics of their reflection through the emotional experience of an ethnic group. Thus, the traditional culture of Kabardians and Balkars pays much attention to the development of restraint, which is determined by a cognitive aspect. Thus, “...original serenity, clarity and credulity of a Balkar soul contradict to life experience and severe nature, which require practicality, business-like attitude, constant tension in foreseeing future events, individualism, a habit to rely on oneself in everything, and a domination of mind over passion. For a Balkar, to lose self-control and to fly into passion means to fall into a state verging on disgrace ...The thinking of a Balkar is whole, it is not impulsive...it always prefers succession in narration" [Jurtubaev 1997:146]. Therefore, a linguistic persona renders this restraint emotional state by the words zhengillik uyatkha k"oyar (Balk.) - [literally: unrestraint (lightheartedness) will lead to disgrace]; nafysyng aytkhanny etme, namysyng aytkhanny et. [literally: do as your conscience, not your feelings, dictates]. Thus, in compliance with a preserved custom in the Balkar culture, a father is not allowed to pay any emotional attention to his children in public, especially in the presence of the elders. It is no coincidence that "...a mountaineer is sensitive and hot; however, he avoids expressing his passion openly", as highlighted by K. Sultanov [Sultanov 1983: 255].

In the culture of the Adyghe people, the manifestation of emotions is also regulated. People should demonstrate patience and restraint. Thus, patience is embodied in proverbs a sigu, zyIezh'e, a si zh'e, zyubyd (Kab.) [Kabardian proverbs, 1994: 90]- literally: my heart, wait, my mouth, hold yourself; gupsysi psal"e, zypl"ykh'i tlys (Kab.) [Kabardian proverbs 1994: 93] literally: first think then speak, turn around, then sit; zh'ym tesu psym yopydzh (Kab.) [Kabardian proverbs 1994: 128]- negatively about a quick, inpatient person; temak" kIykh' (Kab.) - literally: a long throat - a worthy description of a person who can control his emotions; temak" kIeshchI (Kab.) - literally: a short throat - about an impatient, unrestrained person. Tolerance is not only an element of an emotional state and behavior of an Adyghelinguistic persona, but also an essential part of human education. In the Adyghe culture "...tolerance is learned from childhood. The advantage of this quality is explained by the expressions: "Shchenym ya nekh" Ieflyr temak" klykh'shch" (Kab.) - literally: "Restraint is the best virtue"; Utemak" kIykh'yn nekh"re nekh" nesyp syt shchyIe- literally: "What can be compared to a happiness to be restraint in anger"; Shchkh'ekIue zyshkhyr shchkh'e yokhuezhliterally: "He who can control his anger (swallow an offence) lives a long life" [Brazhnokov 1999: 66]. The prescription to observe this restraint in speech determines the manifestation of courage as an "ability to cope with one's angry speech" [Brazhnokov 1999: 66]. Obviously, 
tolerance is an ethnic indicator in the emotional culture of every Adyghelinguistic persona. The ethnic ideal of such a linguistic persona in the Adyghe culture focuses on the development of self-control and emphasizedmanifestation of emotions in various life situations. Besides, it activates and appreciates this self-possession in the situation of indignation, anger, and irritation. Generally, emotions are adaptive. Their manifestations become an attempt to get a primary comprehension of the world, which stimulates the development of the human culture and norms of behavior against the background of the surrounding nature. They enable a person to comprehend and render what is spiritually close or unacceptable for him, what is evaluated positively or negatively, what is bad or good etc. In the culture of many peoples, the lexeme litso (Rus.), nape (Kab.) bet (Balk.) (face) indicates person's emotional state. A face is a kind of painting, which reflects person's spiritual state. Generally, a somatic code is treated as one of the most efficient for expressing emotions, since it encompasses almost all parts of the body. For example, a Russian linguistic persona uses the somatisms golova (head), glaza (eyes), pyatki (heels), ruka (hand), nogi (legs) etc. actively. A feeling of sadness is connoted in the unit povesit golovu -to hang down one's head, a feeling of fear dusha ushla v pyatki -[literally: a soul went down to heels], a feeling of confusion and despair -ruki opustili'[literally: hands came down], a feeling of feardrozhat kolenki [literally: kneels are trembling] etc. An Adyghelinguistic persona also resorts to a somatic metaphor for rendering the emotional and evaluative state of a person. The expressions $i$ shchkh'er k"ypykhuashch [literally: a head fell down] - a feeling of sadness, loss; i le"nkIapIer shchIekIezezykIashch (Kab.) - [literally: kneels rocked].

Unlike many other associations, the ability of the somatism litso (face) to appeal to a color scheme as a symbol of the reflection of person's emotional state is ethnically conditioned. Thus, the characteristic of a face in the context of a colorativ krasnyy (red) be means of verbs zarumyanitsya, raskrasnetsya, vspykhnut (to redden, to turn red, to blush) reflect a reverent feeling of joy, anger, experiences, and emotional tension. The color of a face is an emotional reflection of a person's soul, the increased body temperature vspykhnyt, zasvetitsya, pokrasnet etc. (to blush, to begin to shine, to turn red) is a positive emotional state of a person, while a colorative chernyy (black), temnyy (dark) renders anger and sadness of a person; the lack of face -na nem ne bylo litsa (he had no face) - the lack of color, a pale background - indicates the lack of life, i.e. a strong fear. However, the specifics of the conceptualization of the lexeme litso may determine a large meaningful and cultural connotation. Thus, the word nape in the representation of an Adyghelinguistic persona in the context of a person's emotional state is associated with the Russian words styd, sovestlivost (shame, conscience) as moral 
categories. In the representation of a Russian linguistic persona, there is an expression $u$ tebya net sovesti [You have no conscience], while an Adyghelinguistic persona will say - nape uiIek"ym (Kab.), napenshe (Kab.) - no face. In the representation of an Adyghe linguistic persona, “...almost every human response (thought, emotion or action) is considered from the viewpoint of possibility or impossibility of such combination". "In the consciousness of an Adyghe, a 'face' is an organ of honor and conscience, which is sensitive to the slightest deviations of moral and represents various tones of a moral feeling", writes B.Kh. Bgazhnokov [Bgazhnokov 1999: 71].

The representation of emotional concepts is found in idioms, paroemias, phraseological units, and texts written in a language. Besides, it is a result of conventional and creative metaphors, which are means of person's cognitive activities. Thus, the Balkar linguistic persona expresses a feeling of love in the context of mountains at the associative level, which is understood in the Balkar culture as a symbolic archetypal concept. For example, the appeal of a Balkar soul to high mountains is compared to deep and sincere feeling of love: Seni $k^{\prime \prime}$ atyngda bolsam, zhyuregim Chyg"ady tau teppelege (Balk.) [Kuliev, 2007: 59] literally: When you are here, the heart rises to the mountain peaks - the anticipation of anxiety; the sense of danger are embodied in a mountain stone: Men, k"ayda bolg"anymy da bilmey, K"abyr tashy kibik, syn bolama, Eshikde kechemid, kyunmyud, - kermey, K"aya tashlay, tyngylap turama (Balk.) [Kuliev 2007: 147] literally: I do not know where I am, I am calm like a grave stone. I cannot see whether it is day or night in the street, I am silent like a mountain stone. Thus, the feeling of necessary restraint, which is developed in everything including emotions in the traditional Balkar culture, is reflected in the author's lines: “...Auur bushuu kerseng da, tur zhyuregingde basyp.Syndyrma namysyngy, namysdy mynda nasyp" (Balk.) [Zumakulova 1994: p.75] - literally: Even if you experience grief, suppress the pain in your heart. Do not destroy your honor, honor is happiness here. Restraint feelings and covert emotions are emphasized even in the situation of joy and excitement. Thus, the emphasized emotional manifestation, both verbal and non-verbal, in the relations between parents and children is not welcomed. See: "Taulug"a ulan tuug"anda Khazhibekirni yuyyunyu shoshlug"un zhangy tuug"an zhigitni k"aty auazy buzdu.Nasyply yuyyur, Khazhibekir bla yuydegisi Marziyat, $k^{\prime \prime u u a n c h l a r y ~ k e k y u r e k l e r i n e ~ s y y y n m a y . . . ~ K " u u a n c h l a r y n ~ a ~ a c h y k " ~}$ bildirirge uyaladyla-iylinedile.Adet alay edi" [Gurtuev 1972: 9] - literally: When a son was born in the family of a mountaineer, the quietness of the house was broken by a clear voice of a newborn. Khazhibekir and his wife Marziyat are a happy family, their hearts are 
overwhelmed with joy...However, they are too shy to express their joy openly. This is the custom.

The Kabardian texts also have specific manifestation of basic emotions. Thus, the feeling of joy is quite various in the lexical explication of the language and has a specific representation: dinym ikIyn (Kab.) - a feeling of lost mind - literally: to leave the religion; to become an atheist; figuratively:to become perplexed; to lose one's mind; to lose one's temper; dame k"ytekIashch (Kab.) - literally: wings have grown; he lifted in spirits; duneyr k"utezhyn (Kab.) - literally: to rave and storm, to rage, to make too much noise - literally: to destroy, to smash the world, the universe; duneym tekhuerk"ym (Kab.) - a feeling of limitlessness literally: too big for a world; duneyr khurik"urk"ym (Kab.) - a feeling of joy - literally: the world is not enough!; and duney flyg"ueshch, duney gufleg"ueshch (Kab.) - a feeling of joy, happiness - his world is beautiful and joyous; a feeling of fear: gur dzapekIe iIyg"shch - to fear, to be in constant anxiety - literally: to hold one's heart by the tips of one's teeth;zhenet $b z u$ (Kab.) - literally: a paradise bird - symbolizes purity, sincerity, joy; nalk"utnalmes (Kab.) - emerald stones - as a symbol of spiritual richness, and, therefore, a feeling of emphasized happiness; IэфI (Kab.) - literally: sweet - light soul - with lightness and delicacy of a paradise bird's flight - zhenet bzuue di gur zol"ate (Kab.) - literally: a heart flies like a paradise bird; a feeling of joy is equaled to the perception of shining sky, which resembles the glitter of emerald stones, while the earth is likened to the most beautiful carpet: Psori mekh"u zeue dakhe, IefI! Zhenet bzuue di gur zol"ate K"ytIfoshchI guakIueu duneyri chef. Melyd uafer nalk"utnalmesu, ShchIyl"er mekh"u alerebg"u dakhekIey(Kab.) [Utizhev 2010: 20] literally: Everything becomes beautiful and delicious! A heart flies (trembles) like a paradise bird. The world seems beautiful and drunk. The sky shines like emerald stones, the Earth becomes the most beautiful carpet.

The peculiarities of a cognitive level in the structure of an ethnocultural linguistic persona is also found in revealing the codes of culture as a key to the understanding and comprehension of the specifics representations of some meanings and ideas, and the peculiarities of thinking of an ethnic group. Thus, to represent the feelings of joy and excitement, an Adyghelinguistic persona often uses a zoomorphic code: $k^{\prime \prime} a k^{\prime \prime} e-p s h c h I y p s h c h I u\left(\right.$ Kab.) $-k^{\prime \prime} a k^{\prime \prime} e-$ chuckle literally: with fun, joy, and excitement // “...Auere, ui lezh'eg"u k"ebdzhakher gupyshkhue kh"uиe k"yshchIykh'eri, k"ak"e-pshchIypshchIu Ienem k"etIysekIashch" [Utizhev 2010: 145]; a somatic code, which is considered the oldest and the most meaningful, since a person begins cognizing the world around by cognizing oneself: a feeling of joy - and Iupekher zetemykh'ezhu (Kab.) - literally: lips do not put together, // “...Beg"eush shym k"epsykhashch, 
guflere and Iupekher zetemykh'ezhu” [Mafedzev 1992: 19]; feeling of perplexity Iepel"apesys kh"uaue (Kab.) - literally: in a state when hands and legs tremble; kIerekh"uashch (Kab.) - literally: to begin to whirl in perplexity // Ui gum paptsIe guer $k^{\prime \prime} y l^{\prime \prime}$ Iesa khuede uk"askIeri, tIekIui Iepel"apesys ukh"uaue ue k"epIetashch trubker [Utizhev 2010:146]; and shchkh'er fledzherezykh' kh"uaue (Kab.) - literally: head became dizzy // “...i shchkh'er fledzherezykh' kh"uaue...abykIe i ner k"imykIyu” (Kab.) [Mafedzev 1999: 6]; a feeling of surprise - i zh'er Iurykhuaue (Kab.) - literally: to fall out of the mouth, to eat with one's mouth open with surprise // "Imys $i$ ifyzym i zh'er Iurykhuaue llykher zepipl"ykh'yrt, psal"ekIe shchyg"upshchezha nekh"ey" [Mafedzev 1999: 36]; i nitlyr... kh"ureibze kh"uat (Kab.) - literally: eyes became round because of surprise // "TsIykhubzym i nitlyr pshchykh'eshchkh'e bzhenym eshchkh'u kh"ureibze kh"uat.Apkhuede tel"ydzhe aby yaluataue zekhikhatek"ym... “ [Mafedzev 1999: 37]; sense of dissatisfaction - i temak"ym fIel"shch (Kab.) - literally: is hanging in the throat // "...Apkhuedeu gupsyseure...i zhag"ueu $i$ temak"ym fIel"u" [Mafedzev 1999: 8]; feeling of discontent - ди пэр зэхуэтшауэ [Utizhev 2010: 34]; a feeling of shame - “...si naper mesri...» (Kab.) - literally: a face is burning: «...Tobe, Dyk"ue, ar daue uigu k"ekIykha? Si naper mesri ig"ashchIe...»[Mafedzev 1999: 32]; feeling of pain - shchIym shchIikhuenu meuz (Kab.) - it aches, as if driving underground [Utizhev 2010: 44]; a feeling of a severe pain - kIuetsIkIe ig"evashch (Kab.) - literally: is boiling inside. In the Adyghe culture, the feeling of restraint and ability to be flexible and tolerant is of value. This is represented in such phrases as dechykhyn - to cede, zyshyIen - to restrain oneself // "Aue Dakhenag"ue tsIykhuzetett, dechykh ishchIert..."(Kab.) [Mafedzev 1999: 30] literally: However, Dakhonaguo is a balanced person. He can be flexible; “...i Iupekher mepIezh'azh'e, i Iepekher mepeshchashche...EmykIushch, ig"ue kh"uashch zyshyIe pkhel"ynu, udezykh'ekhyr tsIykhukhem zygueryre yashchypkh"uтenu, yashchybg"epshchkIunu...aue yape ed"yg"uer i bzegupem pokIerekh"ukI»" (Kab.) [Mafedzev 1999: 28] - literally: lips are stirring, fingers are itching...it's a shame, it's time to become more reserved, I should conceal my feelings, however, all this is still on the tip of my tongue; strong feelings and emotions of love are rendered by means of a metaphor, which asserts something protected and warm - tslykhum khuakh"ume khuabag"[Kab.] - literally: warmth that is protected for people // "Shchkh'eg"use". Ue pfIekh'elemetu a psal"e uzemysar, pfleg"eshchIeg"uenui uepl"yrt nekh"yfI dydeu yal"ag"u tsIykhum khuakh"ume khuabag"ymkIe uzydeguesha Zhansekh"u... [Utizhev 2010:143] - literally: A spouse. An unusual word for you. You are looking at your beloved, for whom you protectwarmth and with whom you share this warmth, with surprise and admiration...This is Zhansokh... 
Emotional concepts in the structure of a linguistic persona are universal for ethnic communities; however, their representation and the index of emotionality enable to define the specifics of ethnic emotional perception and evaluation of the world around. A paradigm of any language has many components and tones of emotions and feelings inherent to a person. A set of evaluative semantic fields as a scale of ethnocultural and panhuman values reflects the specifics of the world picture in the linguistic consciousness by means of binary oppositions as one the most relevant principles of world categorization. Indeed, an evaluative categorization of its various fragments, i.e. the juxtaposition of features and properties of objects of reality with binary categories "good" (positive evaluation) and "bad" (negative evaluation), which find various verbal representations in a language and whose axiological status is not doubted, occupies a special place in the conceptualization of the world. N.N. Boldyrev assumes that evaluative categorization is "grouping objects and phenomena into relevant evaluative classes and categories depending on the type of their evaluation, i.e. a system of evaluative categories (a statistic aspect), or imaginary juxtaposition of an object or a phenomenon with a certain evaluative category (a dynamic aspect)" [Boldyrev 2002: 104]. Let us compare these reasoning with the data of linguistic research.Thus, the emotional manifestation of many feelings is represented by a lexeme serdtse (Rus.) - gu (Kab.) (heart). This is a panhuman and universal concept. However, ethnic cultures show the peculiarities of its representation at the level of representations and objectivation. Thus, an Adyghelinguistic persona juxtaposes a feeling of joy, sadness, mental disturbance, anxiety and lack of selfassurance etc. with the idiomatic expressions, where the lexeme $g u$ is crucial. Thus, the researcher Z.Kh. Bizheva notices that the concept $g u$ is represented in the following linguoculturemes: “...guzeven - to worry, to trouble, to be anxious (from gu - heart and zev narrow, tight); guk"eue - offence, indignation (from gu - heart and euen - to strike); gunyk"uen - to become sad, to become upset (from gu - heart and nyk"ue - half); guryfI - a good mood, friendliness (from $g u$ - heart and fIy - good) etc. The epithets with a concept guhave metaphoric ethnocultural semantics. Thus, the Adyghe call a senseless person gu Iuv (literally: "thick heart). They call a kind and sensitive person gu pIashchIe (literally: "thin heart"); an indifferent person - gu shchIyIe (literally: “cold heart") etc. [Bizheva 2014: 111]. The Kabardian-Russian phraseological dictionary contains 155 dictionary articles, where most phraseological units represent emotional and sensitive state of a carrier of a language and culture: gum euen 1. To hurt, to offend someone; 2. To become upset, to perceive something as a severe grief [literally: to strike in the heart] [Kabardian-Russian phraseological dictionary 1963: 36]; gum tekhuen to endure, to bear, to stand [literally : to fit in the heart] [Kabardian- 
Russian phraseological dictionary 1963: 36]; gur g"ezhenyn 1. To encourage oneself, to feel stronger. 2. To become a little drunk [Kabardian-Russian phraseological dictionary 1963: 38]; gum khykh'en to touch the depth of heart [literally: to enter the heart] [Kabardian-Russian phraseological dictionary 1963: 41] etc. Therefore, it is no coincidence that in the consciousness of an Adyghelinguistic persona, a lexemeguis a cultural and linguistic concept and a specific minimal cultural text, whose semantics renders many specific emotional tones of a human soul. Thus, in the abstract from B. Utizhev's short story Gum i Tezyr (Kab.) [Utizhev 2010a] - "That which is many in a soul" (literally) - a concept $g u$ as a component of word formation is manifested, first of all, at the cognitive level of a linguistic persona, which takes a walk down memory lane: “...Argueru zyshIypIekIe k"oukI gushchIer k"yzezyg"edzekI pshynal"er. Guk"inezh kh"ua pshynal"er...Ue ushchysshch, Maryat... Gupsyse kuum ukhetu.Khet ue a gupsyse kh'el"ekher k"ypkhuezykh'ar? ...Guk"inezh kh"ua mo pshynal"era? Kh'eue, Maryat, akher k"ypkhuezyshar ui gurshch. Serashch... Se sytym dezhi k"yzdyzokh'ekI a zhyzh'e k"iIukI pshynal"em ar k"yzeshchIag"estezha k"udeyue arashch...Zeg"ashchIe, Maryat: gum zyri shchyg"upshcherk"ym.'[Utizhev 2010a:143] The abstract from the text is emotional and sensitive. It renders the internal state of a heroine, who has some feelings that prevent her from calming down. This trouble enhances with years and it is the heart (gu), which is full of pain and anxiety. Using the emotional concept $g u$ (Kab.) as a basic crucial linguacultureme, which represents an emotional and sensual paradigm in the structure of an ethnocultural linguistic persona, the author renders delicately the mood of a person plunged into her thoughts and enhances its trouble and anxiety. A linguistic personaobjectivizes such emotions as "a painful reminiscence that turns the heart (literally)-gushchIer k"yzezyg"edzekI (Kab.); "unforgettable feelings" - guk"inezh kh"ua pshynal"er(Kab.) literally:music of an accordion kept in the heart; "anxious feelings and thoughts"-gupsyse kuu, gupsyse kh'el"ekher (Kab.) - literally: deep thoughts in a lexeme gu as a component of linguistic units; the expression gum zyri shchyg"upshcherk"ym emphasizes the cultural connotation of this lexeme as equity and association with a person himself, his understanding of the world around; it is a means of self-esteem, a reminder of time (compare :akher k"ypkhuezyshar ui gurshch. Serashch... Se sytym dezhi k"yzdyzokh'ekI a zhyzh'e k"ilukI pshynal"em ar k"yzeshchIag"estezha k"udeyue arashch). Being a universal concept, heart(gu) in the consciousness of the author of this text has an ethnocultural content and is a stereotyped measure to evaluate the state of person's internal world, in this case, anxious and troublesome. It is represented as a concentration of human memory. The concept gucan represent and nominate some event and situation, which provoke an emphasized, enhanced 
state of joy in the consciousness of a linguistic persona: duney gufeg"ue ileshch, zerekh'e [Kab.] -a joy for the entire world (literally); duneyr yakhurimyk"uu megufle [Kab.] - he is so glad that the world is not enough for him (Kab.) etc.

The specifics of the representation of a universal concept heart $(\mathrm{gu})$ in the consciousness of an Adyghelinguistic persona is represented in an evaluative dichotomy joy and grief as emotions that express different sensual tones of their manifestation, which are embodied in an antonymous pair and indicate positive and negative feelings. See table.

\begin{tabular}{|c|c|}
\hline " $g u$ " as an indicator of positive feelings & " $g u$ " as an indicator of negative feelings \\
\hline gufleg"ue (joy, a joyous event) & guzeveg"ue (grief, a sad event) \\
\hline $\begin{array}{l}\text { a sense of nostalgia: } \\
\text { gupsyse IefI kuedym shchyzyg"afIe si } \\
\text { gushchIag"shchIel" l"akhem[Kab.] - } \\
\text { gupsyse IefI kuedym shchyzyg"afIe si } \\
\text { gushchIag"shchIel" l"akhem [Kab.] - Aby } \\
\text { k"inaue nobi itshch l"eg"unyg"em i } \\
\text { zhygyr[B. Utizhev, 2010: 151. }\end{array}$ & $\begin{array}{l}\text { a sense of disturb: } \\
\text { sigu nyk"ueti [Kab.] - my heart is a half (literally) } \\
\text { “...sigu nyk"ueti, tkh'eue dyk"ezg"eshchIaue } \\
\text { dyzyg"elIezhynum i uzeshchI.. uzynshekheshch } \\
\text { psori, tkh'em i shykurkIe” [Mafedzev 1992:15] }\end{array}$ \\
\hline $\begin{array}{l}\text { a feeling of happiness: gushkhuen (Kab.) - } \\
\text { to have a big heart: } \\
\text { Ue khuabzh'u nasypyfIeu zypl"ytezhyrt, } \\
\text { Maryat. Ugushkhuet } \\
\text {.....// [B. Utizhev, 2010: } 143 .\end{array}$ & $\begin{array}{l}\text { a feeling of sadness, suffering: } \\
\text { gur pytkIukIyu [Kab.] - a heart is melting } \\
\text { “...FatIimeti, zhimyIef shchkh'ekIe, } \\
\text { khutemyg"esebyreu i gur pytkIukIt nyshchkh'ebe } \\
\text { psom”// [B. Utizhev, 2010: 144]. }\end{array}$ \\
\hline $\begin{array}{l}\text { a feeling of dream: } \\
\text { gur zdepl"em Ier nesu [Kab.] - to dream } \\
\text { about the fulfillment of plans: a heart is } \\
\text { watching, hands are doing (literally) } \\
\text { "Sytu gug"e kued sile se, Maryat! A sigur }\end{array}$ & $\begin{array}{l}\text { feeling of strong mourn, terror } \\
\text { guIeg"ue[Kab.] - mourn, state of mourn } \\
\text { "GuIeg"uet aby shchyg"ue ue uzyIupl"ar, } \\
\text { Mariyat"// [B. Utizhev, 2010: 146] }\end{array}$ \\
\hline
\end{tabular}




\begin{tabular}{|l|l|}
\hline $\begin{array}{l}\text { zdepl"ekhem si Ier nesatemi!..."/ } \\
\text { [B. Utizhev, 2010: 144] }\end{array}$ & $\begin{array}{l}\text { worry, trouble, anxiety } \\
\text { guzeveg"uem k"uimyg"egupsysyn shchyIe [Kab.] } \\
\text { - there is something that we cannot even emagine } \\
\text { in the situation of anxiety, isn't it? } \\
\text { "...Arati, guzeveg"uem } k \text { "uimyg"egupsysyn } \\
\text { shchyIe-tsIykhum k"eler leps yashchIre irafu } \\
\text { shchIadze.." // [B. Utizhev, 2010: 186]. }\end{array}$ \\
\hline $\begin{array}{l}\text { a feeling of panic guzh'eg"ue shchIye [Kab.] - a } \\
\text { cold panic, anxiety } \\
\text { “...Guzh'eyg"ue shchIyIem } k \text { "yshchIeusha Zuliy } \\
\text { Iepel"epesys kh"uaue kh'el"k"yr Iuikhashch...”// } \\
\text { [B. Utizhev, 2010: 159]. }\end{array}$ \\
\hline
\end{tabular}

Therefore, we reveal an affective function of a concept, i.e. emotional and evaluative signs found in the coordinate "positive-negatively", "good-bad". We can also refer the connotative meaning joy and sadness to these opposites. In the consciousness of an Adyghe linguistic persona, they are represented by other concepts as the elements of a lexical and semantic group, which enable to reveal cognitive signs used to classify these feelings in the consciousness of their carriers. The representation of the emotional manifestation of the feeling of joy in the texts under study are found (rendered) in a different way; however, their associative ties, semantic constructions and cognitive classification signs are of some interest. These notions fit in the term cultural connotation (V.N. Teliya, 1993) as a way of keeping cultural information.

The verbalization of meanings and their representation in a language is the basic means and principle of development of an ethnic thesaurus as an ethnic dictionary, which involves crucial, dominant words determined by culture, which are relevant for the carriers of a certain culture and language, i.e. an ethnocultural linguistic persona as a cognitive invariant, as a generalized image of the carriers of cultural-linguistic and communicative-activity values, knowledge and attitudes of thinking and behavior.

The uniqueness of an ethnocultural fragment in the structure of a linguistic persona is determined by specific principles of explanation and transfer of universal phenomena, 
processes, and objects. Therefore, it has its individual system of cognitive and linguistic schemes and models, which can be used to make an ethnocultural mini-dictionary of a linguistic persona under study. Thus, the emotional expressions nasyp dileti (Kab.) - literally: we have happiness - we are lucky; si psem ishchIert (Kab.) - literally: my soul knew, felt; Ie shchabe - mak" khuabe; mak" guape( Kab.) - literally: soft hands - a warm voice, a polite voice etc. As we see, emotions and feelingsrepresented in a languagegive someethniczest it to the thoughts and words of a linguistic persona and regulate its actions and behavior. This emphasizes that the consciousness of an emotional linguistic persona is determined by a specific worldview of a particular people. Besides, it is impossible to make a literal translation of these expressions in the context of the revelation of a cultural connotation in these speech formulas.The ethnic plan of emotions and feelings is a result of the existence of a particular society, which elaborates the traditional experience, customs, morals, norms etc. or already has them. It is important that people in one culture and with one language undoubtedly have similar (relatively) perception of the world, their metaphorical comprehension and interpretation of the reality coincide, their emotional evaluation of the processes and phenomena around them have many points of contact and coincidence.

Thus, the cognitive activity of a person based on feelings and emotions helps him, on the one hand, to adapt to the environment, and, on the other hand, to develop his own subjective world, which is cognized, thought, and comprehended by a person in compliance with his needs, embodied in the consciousness as processed and selected from all similar processes and phenomena and fixed as a popular and necessary for a person. Emotions and feelings as primary adaptive means of a person are activated during his cognitive activity and enhance the specifics of emotional perception of the world by a certain community of people. Emotions are mostly subjective and personal. However, they are typical for a group of people united ethnically, culturally and linguistically. In other words, there is some emotional and sensual linguistic layer, which acquires a standardized, typed and stereotyped sign as a result of similar emotional and sensual worldview. Emotional state of a person is indicative of a culture, which has universal or basic concepts and ethnic or emotional and sensual concepts.

\section{REFERENCE}

1. Bizheva Z.Kh. Yazykovaya Kartina Mira i Etnostereotipy (na Materiale KabardinoCherkeskogo Yazyka) [Linguistic Picture of the World and Ethnic Stereotypes (on the material of Kabardian and Circassian Language]. Bulletin of Dagestan Scientific Center. 2014.No 52. Pp. 110-112. [In Russian] 
2. BgazhnokovB. Kh. AdygskayaEtika [AdygheEthics]. B.Kh. Bgazhnokov. Nalchik. The publishing center El-Fa. 1999. 96 p.[In Russian]

3. Bokin G.I. Model Yazykovoi Lichnosti [A Model of Linguistic persona]. A thesis for a Doct. Sc. (Filosophy). 1984.[In Russian]

4. Boldyrev N.N. Struktura i Printsipy Formirovaniya Otsenochnyh Kategoriy [The Structure and Principles of Development of Evaluative Categories]. With Love to Language: A collection of academic works. Dedicated to E.S. Kubryakova. Moscow-Voronezh: Institute of Linguistics of the Russian Academy of Sciences, Voronezh State University, 2002. Pp. 102-114.[In Russian]

5. A. Vezhbitskaya Ponimanie Kultur Cherez Posredstvo Klyuchevyh Slov [Understanding of Cultures by Means of Key Words]. Moscow, 2001. 288p.[In Russian]

6. VorkachevS.G. SopostavitelnayaEtnosemantikaTeleonomnykhKontseptov "Lyubov" i "Schastye" (Russko-AngliyskieParalleli) [ComparativeEthnosemanticsofTeleonomicConcepts "Love" and "Happiness" (RussianandEnglishparallels)]. Monograph/ S.G. Vorkachev. Volgograd. Peremena, 2003. 164p.[In Russian]

7. GerderI.G. IdeikFilosofiiIstoriiChelovechestva. Moscow. Nauka, 1977. 703p. (IdeenzurPhilosophiederGeschichtederMenschheit). Translated and commented by A.V. Mikhailov. Executive editor A.V. Gulyga.[In Russian]

8. Humboldt W. von Izbrannye Trudy po Yazykoznaniyu [Selected Works in Linguistics] // W. Humboldt. Moscow. Progress, 1984. 398 p. [In Russian]

9. Humboldt W. von Yazyk i Filosophiya Kultury [Language and Philosophy of Culture]. Moscow. Progress, 1985. 415 p.[In Russian]

10. Weisberger J.L. Rodnoi Yazyk i Formirovanie Dukha [Muttersprache und Geistesbildung]. Translation from German, introduction and comments by O.A. Radchenko. the 2 nd edition amended and supplemented. Moscow. Editorial URSS, 2004. 232 p. P. 90.[In Russian]

11. Jurtubaev M.Ch. Dusha Balkarii [The Soul of Balkaria]/ M.Ch. Jurtubaev. Collection of articles. Nalchik. Elbrus, 1997. 232 p. [In Russian]

12. Zykova I.V. O Lichnosti: Lingvokulturologicheskie Zametki [Persona: Linguistic and Cultural Comments] // Language. Consciousness. Communication. Issue 46. Collection of academic papers devoted to V.N. Teliya. Moscow, 2013. 142p.[In Russian]

13. ZykovaI.V. KulturaKakInformatsionnayaSistema: Dukhovnoe, Mentalnoe, Materialno-Znakovoe. [Culture as Information System: Spiritual, Mental, Material and Sign- 
Oriented]. Monograph. Moscow, 2011. 368 p. Karaulov Yu. N. Russkiy Yazyk i Yazykovaya Lichnost [Russian Language and a Linguistic persona]. Moscow. Publishing house LKI, 2007. 264 p.[In Russian]

14. Krasavskiy N.A Emotsionalnye Kontsepty v Nemetskoi i Russkoi Lingvokulturah [Emotional Concepts in German and Russian Linguistic Cultures]/ N.A. Krasavsky Volgograd: Peremena, 2001. 495p.[In Russian]

15. Kondratyeva O.N. Metaforicheskoe Modelirovanie Kontsepta "Dusha" v Drevnerusskoi Lingvokulture [Metaphoric Modelling of the Concept "Soul" in Ancient Russian Linguistic Culture]. M. Pero, $2014 . \quad 188 \mathrm{p}$. Sedykh A.P. Etnokulturalnye Kharakteristiki Yazykovoi Lichnosti (na Materiale Frantsuzskoi Yazykovoi Lichnosti) [Ethnocultural Features of a Linguistic persona (on the Material of a French Linguistic persona)]: a thesis for a Doct.Sc. (Philology). Belgorod, 2005. 418 p. [In Russian]

16. Sedykh A.P. Priroda Emotsiy i Ikh Klassifikatsiya v Gumanitarnukh Naukah i Yazykoznanii [The Nature of Emotions and Their Classification in Humanitarian Sciences and Linguistics]. Nauchnye Vedomosti. Series Humanitarians. 2012. No 6 (125). Issue 13. Pp.108 - 115.[In Russian]

17. Sultanov K.K. Organika Origonala [the Organics of the Original]/ K.K. Sultanov // Druzhba Narodov. 1983. No 6. Pp. 254-255.[In Russian]

18. Tarasov E.F. Vvedenie [Introduction] // Yazyk i Sozhanie: Paradoksaknaya Ratsionalnost [Language and Consciousness: Paradox Rationality]. Moscow. 1993. Pp. 6-15. [In Russian]

19. Teliya V.N. Lingvokulturologiya - Klyuch k Novoi Realnosti Fenomena Vosproizvodimosti Neskolkoslovnykh Obrazovaniy [Linguistic Culture Studies - A Key to New Reality of the phenomenon of Reproducibility of Multi-Word Formations]/ V.N. Teliya, A.V. Doroshenko // Language. Culture. Communication Collection of scientific works in the honor of the jubilee of the honored professor of Lomonosov MSU S.G. Ter-Minasova. Moscow. Gnozis, 2008. Pp. 207-216.[In Russian]

20. Teliya V.N.O Fenomene Vosproizvodimosti Yazykovykh Vyrazheniy [On the Phenomenon of Reproducibility of Linguistic Expressions]. Language, consciousness, communication: Collection of papers / executive editors V.V. Krsnykh, A.I. Izotov. Moscow. MAKS Press, 2005. Issue 30. Pp. 4-42. [In Russian] 
21. Khrolenko A.T. Issedovanie Emotsionalnogo Opyta Etnosa Sredstvami Krosskulturnoi Lingvofolkloristiki [The Research into the Emotional Experience of an Ethnic Group by Means of Cross-Cultural Linguistic Folklore] // Ryabininskiye readings 2007. The proceedings of the 5th research conference devoted to the research into the folk culture of the North of Russia. Petrozavodsk, 2007. Pp. 258 - 261. [In Russian]

22. Chesnokov I.I. Mest kak Emotsionalnyy Povedencheskiy Konsept (Opyt KognitivboKommmunikativnogo Opisaniya v Kontekste Russkoi Lingvokultury) [Revenge as an Emotional Behavioral Concept (the Experience of Cognitive and Communicative Description in the Context of the Russian Linguistic Culture)]. Monograph. Volgograd. The publishing house of Volgograd State Pedagogical University, 2008. 256p. [In Russian]

23. Yazyk kak Sredstvo Translyatsii Kultury [Yazyk as a Means of Culture Translation]. Moscow. Nauka, 2000. 311p.[In Russian]

24. Shakhovsky V. I. National cultural and social cultural aspects of linguistic persona /V.I. Shakhovskiy // Society, language and personality. The proceedings of the All-Russia Research Conference (Penza, October 23-26, 1996). Moscow, 1996. Issue 1. Pp. 29-30.[In Russian]

25. Shakhovskiy V.I. Lingvisticheskaya Teoriya Emotsiy [Linguistic Theory of Emotions]. Monograph. Moscow, 2008. 415 p.[In Russian]

\section{THE LIST OF THE SOURCES OF ILLUSTRATIVE MATERIAL}

1. Zumakulova T.M.Selected: Lyrics and Poems /T.M. Zumakulova. Introduction by Z.Kh. Tolgurov. Nalchik. Elbrus, 1994. 528p. [in Balkarian].

2. Kardanov B.M. Kabardian-Russian phraseological dictionary. Kabardian-Balkar publishing house. Nalchik, 1963. 230c.

3. Kabardian proverbs. Compiled by: Gukemukh A.M., Karadangushev Z.P.. Nalchik. Elbrus, 1994. 324 p. [In Kabardian].

4. Kuliev K.Sh. Collection of works. In 6 vol. Vol. 1. Lyrics. 1934-1962/K.Sh. Kuliev. Introduction by Z.Kh. Tolgurov. Nalchik. Elbrus, 2007. 552 p. [In Balkar].

5. Mafedzev S.Kh. Worthy of a Sad Song. A novel / S.Kh. Mafedzev. Nalchik. Elbrus, 1992. 448p. [in Kabardian].

6. Utizhev B.K. Works: lyrics, sonnets novellas, pieces / Nalchik. Elbrus, 2010. 372 p. [in Kabardian]. 
7. Utizhev B.K. Gum i Tezyk // Works: lyrics, sonnets novellas, pieces / Nalchik. Elbrus, 2010 a. 143-150 [in Kabardian].

Abbreviations used

Rus. - the Russian language

Kab. - the Kabardian language

Balk. - the Balkar language

How to cite this article:

Bashieva SK, Shogenova M Ch, Dokhova Z R, Tabaksoeva I R. Ethnocultural features of a linguistic persona: the specifics of the representation of universal emotional concepts. J. Fundam. Appl. Sci., 2017, 9(2S), 1638-1661. 